\title{
Determinants of Customer Satisfaction of Public Banks in Nepal
}

\author{
Rajeswor Neupane
}

\begin{abstract}
The study aims to analyze the factors influencing customer satisfaction in public bank of Nepal. The customers of public banks in Nepal are the population of this study. The 150 respondents have been as sample and analytical research design has been adopted in the study. The statistical tools such as mean, correlation and regression analysis have been used to analyze the data using SPSS - 20 version software. The research paper concluded that banks should focus more on increasing tangibles, responsiveness and assurance. The demographic variables age, gender, income level and education level do not have significant differences among the responses of participants.
\end{abstract}

Keywords: Responsiveness, Assurance, Tangibles, Reliability, Empathy, Satisfaction

\section{INTRODUCTION}

Customer satisfaction is the key factor for customer retention and the success of the bank. Identifying and improving the factors that can limit the satisfaction of customer is the crucial step for the bank which wants to be a step forward than its competitors. Customer satisfaction is a long-term strategy. It is difficult to radically alter the perceptions of product quality over a short time horizon. It is also difficult to quickly cultivate reputation for superior customer service. Consequently customer satisfaction is as competitive advantage that is sustainable over the long term (Schnaars, 1991). In the past few years, subject of satisfaction and dissatisfaction have received a great deal of attention from academic researchers. The banking sector is more liberalized and modernized and systematically managed. There are various types of bank working in modern banking system in Nepal. It includes commercial, development, Finance and Micro Finance. Public bank occupies quite an important place in the framework of every economy. It provides capital for the development of industry, trade \& business investing the saving collected as deposit. All the economic activities of every country are greatly influenced by the public banking business of that country. Engel \& Blackwell (1982) defined satisfaction as an evaluation that the chosen alternative is consistent with prior beliefs with respect to that alternative. The satisfaction implies a conscious and deliberate evaluation of outcomes. The satisfaction and dissatisfaction had represented the extreme points on a continuum. High satisfaction or dissatisfaction also is the motivation for sharing with others (Engel, Blackwell, \& Miniard, 1990).

Manuscript received on June 15, 2019.

Revised Manuscript received on June 25, 2019.

Manuscript published on July 30, 2019.

* Correspondence Author

Rajeswor Neupane*, Associate Professor, Tribhuvan University, Nepal Commerce Campus, Kathmandu, Nepal

(C) The Authors. Published by Blue Eyes Intelligence Engineering and Sciences Publication (BEIESP). This is an open access article under the CC BY-NC-ND license (http://creativecommons.org/licenses/by-nc-nd/4.0/)
Banks are striving hard to offer quality service and products to maintain the existing customers and allure the new ones as well. Customers, on the other hand, want the best value for their money so they are always combining around to get the best value. Customer satisfaction can't be limited to short term strategy it's a long term strategy of any firm. Schnaars (1991) explained that when expectation of customers matched the resultant feeling become satisfaction and when expectation does not match than the resultant feeling is dissatisfaction. Engel (1990) explained that the modern management science's philosophy considers customer satisfaction as a baseline standard of performance and a possible standard of excellence for any business organization (Gerson, 1993). The customer satisfaction must be translated into a number of measurable parameters directly linked to people's job. In other words factors that people can understand and influence (Deschamps and Nayak, 1995). Customer satisfaction is generally described as the full meeting of one's expectations (Oliver, 1980). Customer satisfaction could lead to stronger customer base which is a competitive advantage to the institutions (Salifu, Decaro, Evans, Hobbs \& Iyer, 2010). Due to the importance of customer satisfaction, it has become academics' and practitioners' interests in service industry. There is a continuous growth in research of customer satisfaction in retail banking sector (Salifu, Decaro, Evans, Hobbs \& Iyer, 2010). Anderson, Fomell and Lehman (1994) explained that when transacting with banks, customers always judge the level of services and the priority given by bank and finally decide about repurchase behavior. Customer satisfaction level is high when they obtain maximum usage and profit with minimum price (Afsar, Rehman, Qureshi \& Shahjehan, 2010). On the contrary, dissatisfaction arises when pricing does not accommodate customers' needs. For instance, the interest rates on loans, charges on the usage of online services and the processing fees are among the factors which determine customer satisfaction (Afsar, Rehman, Qureshi \& Shahjehan, 2010). Customer satisfaction is found to leave an impact directly on cognitive evaluation of consumers and affective responses. In addition, satisfaction is a kind of cognitive state that solicits feedback from customer after service or product consumption. The mentioned model identified that customer satisfaction is a function of causal relationship between expectation and service performance (Salifu, Decaro, Evans, Hobbs \& Iyer, 2010). Hence, the study aims to determine the determinants of customer satisfaction of public banks in Nepal. Shrestha (2018) concluded that the overall customers were satisfied with service quality of the commercial banks. Hence the level of customer satisfaction of the commercial banks on the basis of service quality could be considered satisfactory. 


\section{Determinants of Customer Satisfaction of Public Banks in Nepal}

Chulam, Haroon and Zahid (2010) found that religious and profitability reasons were the most imperative variable for selection of an Islamic bank. Customers preferred to dealing with Islamic banks because these were providing them the same facilities as were offered by the conventional banks but they had a sense of satisfaction that an Islamic bank also operates in compliance with basic principles of Islamic System of Finance. The results of the study highlighted that many of the customers were dealing only with conventional bank because Islamic banks did not have sufficient branch network and were not offering some of the products as were offered by the conventional banks. The findings of the study concludes that customers were ranking religious \& profitability reasons, low service charges, staff friendliness, efficiency very highly. But insufficient branch network and non-availability of some products by the Islamic banks were urgent reasons to deal with conventional banks. The study also concluded that age was significantly related to advertising and religious reasons; gender with the location of branch and religious reasons; education with service charges and religious and profitability reasons; income with

Schiffman, et al (2010) advocate that customer satisfaction is identified by a response that pertains to a particular focus (purchase experience or associated product) and occurs at a certain time (post purchase or post consumption). This definition supports the view that a consumer's level of satisfaction is determined by growing experience at the point of contact with the supplier. ( $\mathrm{He}$ concluded that customers of private and public sector banks are satisfied except some tangibles and behavioral factors of the banks employees due to the policies, strategies for tangibles and inefficiency of the employees. So, it is imperative to consider tangibles and behavioral factors of the employees to enhance the level of satisfaction in Public banks.

John \& Linda (1976) investigated the relationship between expectations, performance and satisfaction. The findings revealed that when a customer judges the performance of a product, he usually compares a set of performance outcomes that are expectations. The product is then likely to be considered as dissatisfactory or satisfactory. Tesfom and Birch (2011) stated that young and older bank customers differ significantly in their satisfaction levels. For instance, younger customers are more likely to easily change their banks, but for banks to retain them, they need to offer more meaningful incentives to younger customers than older customers.

Kanning and Bergmann (2009) on the other hand distinguish customer satisfaction differently using the confirmation/disconfirmation paradigm model. According to the authors, satisfaction or dissatisfaction is determined by the difference between the customers' expectations (E) of a particular product or service and their perceptions of the actual performance $(\mathrm{P})$ of this product or service. The authors further note that, when customers' expectations are fulfilled, the result is satisfaction and if not, dissatisfaction occurs.

Satisfied customers are also able to positively communicate their experiences with potential customers (Narteh and Kuada, 2014). In addition, attracting new customers is usually more costly and this creates the necessity to satisfy confidentiality and advertising.

customer so as to retain them (Kaura, 2013).On the other hand, dissatisfied customers can influence 1,000 customers to have a negative feeling about businesses (Gupta and Dev, 2012) Customer satisfaction in a commercial bank in addition to exact economic parameters is significantly formed by feelings that these customers have while communicating with the bank. (Belás, Holec, Demjan, and Chochol'áková, 2014). Chiguvi (2016) explains that customer satisfaction is the customer's feeling that a product has met or exceeded his/ her expectations. Kaura (2013) had done a research on customer loyalty in Indian commercial banks. The researcher categorized service convenience into decision convenience, access convenience, transaction convenience, benefit convenience and post benefit convenience. The decision convenience had influenced customer satisfaction more than the other dimensions of service convenience. Chiguvi (2016) explains that customer satisfaction is the customer's feeling that a product has met or exceeded his/ her expectations.

\section{Theoretical Framework}

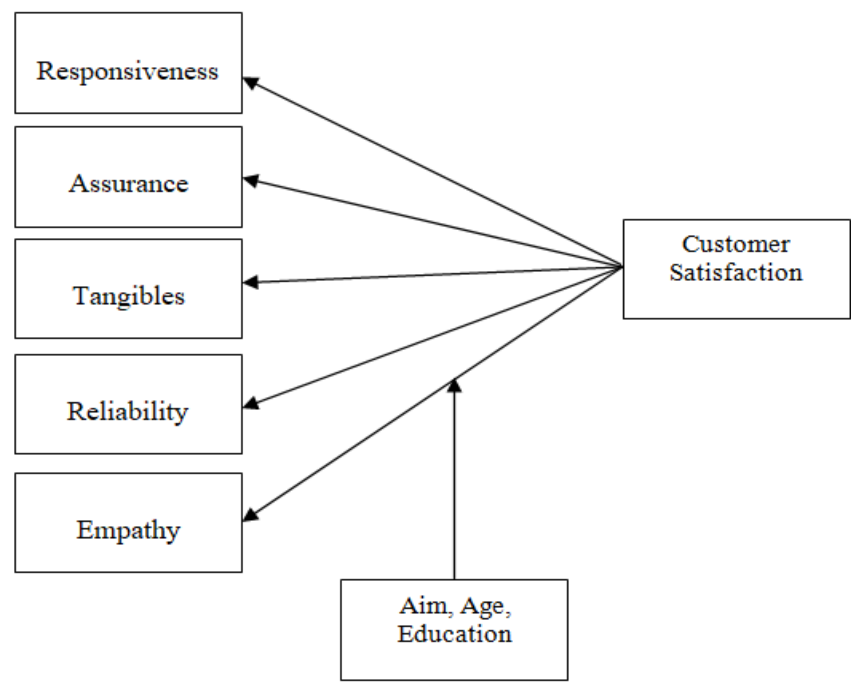

Zeithaml and Bitner (2003) had argued that customer satisfaction had become the major contributor for enhancing the service company such as long term profitability, customer loyalty, and customer retention.

\section{OBJECTIVE OF THE STUDY}

To examine the factor influencing customer satisfaction in public banks of Nepal.

\section{Hypothesis}

$\mathbf{H}_{1}$ : there is no significance difference between male and female customers with customer satisfaction on public bank.

$\mathbf{H}_{2}$ : Age group do not have significance difference in customer satisfaction on public bank.

$\mathbf{H}_{3}$ : the customer satisfaction on public bank across different education levels of customers do not have significance differences.

$\mathbf{H}_{4}$ : the customer satisfaction across different income levels of customers do not have significance differences.

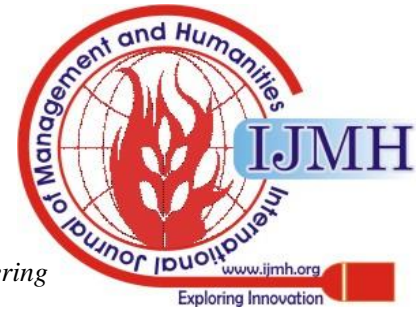




\section{METHODS AND MATERIALS}

The study had used descriptive and analytical research design to test the research hypothesis. It attempts to cover the variable which affects the customer satisfaction on public bank. The plan of gathering information is self administered structured questionnaire. Two variables have been examined: they are customer satisfaction (dependent variable) and responsiveness, assurance, empathy, tangibles and reliability (independent variables). The SPSS 20 version had been used to analyze the data. The correlation and regression analyzes had analyzed the data.

$\mathrm{Y}=\mathrm{a}+\mathrm{b}_{1} \mathrm{x}_{1}+\mathrm{b}_{2} \mathrm{X}_{2}+\mathrm{b}_{3} \mathrm{X}_{3}+\mathrm{b}_{4} \mathrm{X}_{4}+$

Quantitative design is found to be more suitable than qualitative design in the study.

$\mathrm{Y}=$ Customer satisfaction

$\mathrm{X}_{1}=$ Aim

$\mathrm{X}_{2}=$ Age

$\mathrm{X}_{3}=$ Education

$\mathrm{X}_{4}=$ Responsiveness

$\mathrm{X}_{5}=$ Assurance

$\mathrm{X}_{6}=$ Tangibles

$\mathrm{X}_{7}=$ Reliability

$\mathrm{X}_{8}=$ Empathy

The study had been conducted in the Kathmandu city. For research purpose, the survey method had been used to collect the primary data. Sample unit was an account holder of public bank drawn as sample from convenience sampling method.

Out of 165 questionnaires distributed, 150 were responded. Therefore, the whole analysis of result had been based on 150 questionnaires Table 1 represents profile of respondent covered under the study.

\section{RESULTS}

Table: 1. Characteristics of the Respondents Covered under the Study

\begin{tabular}{|c|c|c|}
\hline Dimension & \multirow{2}{*}{ Frequency } & \multirow{2}{*}{ Percent } \\
\hline Gender & & \\
\hline Male & 63 & 42 \\
\hline Female & 87 & 58 \\
\hline Total & 150 & 100 \\
\hline \multicolumn{3}{|l|}{ Age } \\
\hline $20-25$ Yrs & 72 & 48 \\
\hline 25-30 Yrs & 63 & 42 \\
\hline 30-35 Yrs & 9 & 6 \\
\hline 35 or More & 6 & 4 \\
\hline Total & 150 & 100 \\
\hline \multicolumn{3}{|l|}{ Bank Name } \\
\hline ADB & 40 & 26.7 \\
\hline RBB & 65 & 43.3 \\
\hline NBL & 45 & 30 \\
\hline Total & 150 & 100 \\
\hline \multicolumn{3}{|l|}{ Education } \\
\hline SLC & 1 & 0.7 \\
\hline Intermediate & 9 & 6 \\
\hline Bachelors & 75 & 50 \\
\hline Masters or Above & 65 & 43.3 \\
\hline Total & 150 & 100 \\
\hline \multicolumn{3}{|l|}{ Types of Employer } \\
\hline Private & 54 & 36 \\
\hline
\end{tabular}

\begin{tabular}{|c|c|c|}
\hline Public & 51 & 34 \\
\hline Self Employed & 45 & 30 \\
\hline Total & 150 & 100 \\
\hline \multicolumn{3}{|l|}{ Monthly Income } \\
\hline Less than 30000 & 107 & 71.3 \\
\hline $30000-60000$ & 27 & 18 \\
\hline $60000-120000$ & 14 & 9.3 \\
\hline 120000 or more & 2 & 1.3 \\
\hline Total & 150 & 100 \\
\hline \multicolumn{3}{|l|}{ Professional } \\
\hline Business & 31 & 20.7 \\
\hline Service & 43 & 28.7 \\
\hline Student & 70 & 46.7 \\
\hline Housewife & 2 & 1.3 \\
\hline Others & 4 & 2.7 \\
\hline Total & 150 & 100 \\
\hline
\end{tabular}

\section{Field Survey 2018}

Questionnaire has been designed in Likert scale format in most of the cases to get the answer of the respondents. It is a rating scale which requires the respondent to indicate a degree of agreement or disagreement with each of a series of statement about the stimulus objects. After the questionnaires were collected, the relevant information was drawn. Out of 150 respondents,63 respondents (42 percent) were male and 87 respondents (58 percent) were female, indicating that the percentage of female was more than male respondents in term of age group, majority of the respondent were between the 20 to 25 years of age and then 35 or more years were minimum. It has shown that customer satisfied was dominated by youngsters. In terms of education status, highest percentage of respondents has completed graduation or bachelor degree education (75 percent) followed by post-graduation and above (65 percent) the higher education (9 percent) and minimum for SLC (1 percent) which indicates that majority of respondents were educated customers.

\section{CORRELATION ANALYSIS}

Correlation coefficient between dependent and independent variables reflect the relationship and association among the variables. After the extraction of different variables, it is to estimate the association between customer satisfactions of public bank. The customer satisfaction was considered as dependent variable and responsiveness, assurance, tangibles, reliability and empathy were considered as independent variables. The correlation coefficients between customer satisfaction and their variables are presented in the table 2.

Table 2. Correlation Matrix

\begin{tabular}{l|l|l|l|l|l|l|}
\hline Items & $\begin{array}{l}\text { Custo } \\
\text { mer } \\
\text { satisfa } \\
\text { ction }\end{array}$ & $\begin{array}{l}\text { Respons } \\
\text { iveness }\end{array}$ & $\begin{array}{l}\text { Assur } \\
\text { ance }\end{array}$ & $\begin{array}{l}\text { Tang } \\
\text { ibles }\end{array}$ & $\begin{array}{l}\text { Relia } \\
\text { bility }\end{array}$ & $\begin{array}{l}\text { Emp } \\
\text { athy }\end{array}$ \\
$\begin{array}{l}\text { Custo } \\
\text { mer } \\
\text { satisfa } \\
\text { ction }\end{array}$ & 1 & $0.774 * *$ & $\begin{array}{l}0.753 \\
* *\end{array}$ & $\begin{array}{l}0.680 \\
* *\end{array}$ & $\begin{array}{l}0.585 \\
* *\end{array}$ & $\begin{array}{l}0.43 \\
4 * *\end{array}$ \\
\\
Published By: \\
Blue Eyes Intelligence Engineering \\
\& Sciences Publication
\end{tabular}




\section{Determinants of Customer Satisfaction of Public Banks in Nepal}

\section{A. Regression Analysis}

Table 3. Regression Analysis

\begin{tabular}{|c|c|c|c|c|c|}
\hline Model & Beta & $\begin{array}{c}\text { Std. } \\
\text { Error }\end{array}$ & $\begin{array}{c}\text { t- } \\
\text { value }\end{array}$ & $\begin{array}{c}\text { p- } \\
\text { value }\end{array}$ & VIF \\
\hline Constant & $\begin{array}{c}- \\
0.198\end{array}$ & 0.117 & $\begin{array}{c}- \\
1.698\end{array}$ & .092 & \\
\hline Responsiveness & 0.307 & 0.043 & 7.179 & 0.000 & 1.875 \\
\hline Assurance & 0.385 & 0.041 & 9.407 & 0.000 & 1.574 \\
\hline Tangibles & 0.216 & 0.040 & 5.433 & 0.000 & 1.726 \\
\hline Reliability & 0.048 & 0.033 & 1.444 & 0.151 & 1.630 \\
\hline Empathy & 0.123 & 0.029 & 4.303 & 0.000 & 1.180 \\
\hline R-square=0.833, DW=1.941, F= 143.564, p-value $<0.01$ \\
\hline
\end{tabular}

Table 3 represents the result of the regression model on factors influencing customers satisfaction on public bank is significant at 1 percent level of significant $(\mathrm{p}<0.01)$ with the value of $\mathrm{F}=143.564$. Hence there is sufficient evidence, at the 1 percent level of significance, that there is a linear relationship of responsiveness, assurance, tangibles and empathy (independent variables) with customer satisfaction. Most of the variables have been found significant at I percent level of significance. The value of DW shows that there is no problem of autocorrelation. It would also help to implement empathetic approach. It can be concluded that there is no such big differences among the responses of participants belonging to different age group, gender, income level and education level.

To know the difference in opinion of male and female on customer satisfaction, independent sample t-test was carried

Table 4. Customer Satisfaction between Male and Female

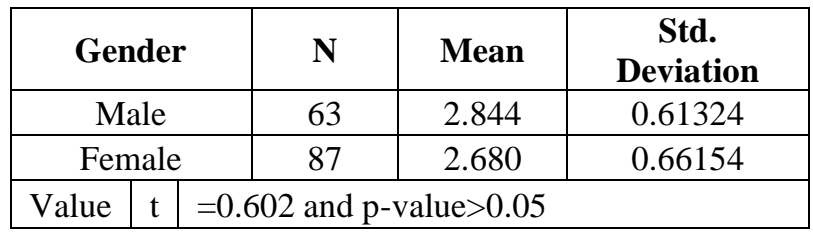

Table 4 shows that the p-value is greater than 0.05 , and +statistic is ten than 2 which indicates that the mean of opinions of both male and female are not seen significantly different. It indicates that there is no significant difference in the opinion towards customer satisfaction between male and female respondents.

ANOVA has been used to examine the association of customer satisfaction across different age group. Table 4.8 shows the concrete of result of this test.

Table 5. Customer Satisfaction across Age Group

\begin{tabular}{|c|c|c|}
\hline & F & P-value \\
\hline Between Groups & 73652 & 0.000 \\
\cline { 1 - 1 } Within Groups & & \\
\hline
\end{tabular}

Table 5 reflects that the association of age group on customer satisfaction is significant. Overall $F=1.7 .652$, $\mathrm{p}<0.0$ I.This suggest that significant difference has been found across the different age group on customer satisfaction on public bank. Result of one way ANOVA test suggests that the customer satisfaction on public bank across different age group is significant at 1 percent level of out. Following table presents the result of hypothesis testing.

significance $(\mathrm{p}$-value $<0.01)$. The data has the sufficient evidence for establishing the different opinion across the different age group on customer satisfaction on public bank.

One Way ANOVA has been used to examine the across respondents holding different educational degree. Table 6 shows the concrete result of this test.

Table 6.Customer Satisfaction across Education Level

\begin{tabular}{|c|c|c|}
\hline & F & P-value \\
\hline Between Groups & 2.075 & 0.106 \\
\cline { 1 - 1 } Within Groups & & \\
\hline
\end{tabular}

Table 6 reflects that the customer satisfaction on public bank across the level of education is insignificant overall $\mathrm{F}=$ 2.075 and $(\mathrm{p}>0.05)$. This suggests that significant difference has not found across the different education levels on customer satisfaction on public bank Result of One Way ANOVA test suggested that the customer satisfaction on public bank across the different education level is insignificant at 5 percent level of significance ( $p>0.05$ ) which suggests that education level does not differentiate on customer satisfaction on public bank. There is no significant difference across education level on customer satisfaction Result of one way ANOVA test suggests that the customer satisfaction across the different education level is insignificant at 5 percent level of significance (pvalue $>0.05$ ). The data has sufficient evidence for establishing the similar opinion across the customers of different education level.

One ANOVA has been used to examine the across respondents with different level of income.

Table 7. Customer Satisfaction across Income Level

\begin{tabular}{|c|c|c|}
\hline & F & P-value \\
\hline Between Groups & 3.156 & 0.027 \\
\cline { 1 - 1 } Within Groups & & \\
\hline
\end{tabular}

Table 7 reflects that the customer satisfaction across the level of income is significant overall $F=3.156$ and $(p<0.01)$. This suggests that significant difference has been found across the different income levels on customer satisfaction. Result of one Way ANOVA test suggests that the customer satisfaction across different income level is significant at 1 percent level of significance ( $p<0.01)$. The data has the sufficient evidence for establishing the different opinion across the different income level on customer satisfaction.

\section{CONCLUSIONS}

The study findings are based on quantitative survey and interviews of customer on the public banks in Kathmandu Valley. As a part of conceptualizing issues, this study has been theorized based on the available reviews of literature of the customer satisfaction on the public banks.

This study has investigated some of the variables that influence customer satisfaction. The result and the analysis show that the banks create a good impression and thus satisfy their customers by the service quality they provide.

Published By:
Blue Eyes Intelligence Engineering \& Sciences Publication 
The impact of service quality over the customer satisfaction is found through the analysis. From the data collected it was found that the positive service quality can increase a satisfactory customer group which effects the overall satisfaction of the organization and hence public sector customers are satisfied.

Service qualities of public banks were measured by using descriptive analytical method. It has found that a customer gives highest importance to assurance dimension. Within that assurance dimension they give more focus on safety of transaction, consistency in service etc. From Analysis it was found that a customer gives second importance to responsiveness of bard (employees. It includes various criteria like, promptness in giving service, willingness to help customers etc. Customer gives third preference to tangibles factor and the empathy factor.

So, banks should give more focus on increasing tangibles, responsiveness and assurance. For that they can give training to their employee which will help them to give personalized service. It will also help to implement empathetic approach. It can be concluded that there is no such big differences among the responses of participants belonging to different age group, gender, income level and education level.

\section{REFERENCES}

1. Afsar, B., Rehman, Z., Qureshi, J., \& Shahjehan, A. (2010) Determinants of customer loyalty in the banking sector: The Cue of Pakistan. African Journal of Business Management, 1040-1047.

2. Anderson, E., \& Sullivan, M. (1993). The Antecedents and Consequences of Customer Satisfaction for Firms. Marketing Science. 12, 125-143.

3. Chiguvi, D. (2016).Impact of Total Quality Management on Customer Satisfaction in the Retail Sector: Case of indigenous Supermarkets in Botswana. European Journal of Business and Management, ISSN (Paper) 2222-1905.

4. Engel, F. J., Blackwell, D. R., \& Minard, W. P. (1990). Consumer Behavior. USA: The Dryden Press.

5. Engel, J. F., \& Blackwell, R. D. (1982). Consumer Behavior. Japan: The Dryden Press.

6. Gearson, R. (1993). Measuring Customer Satisfaction. California: Crisp Publication.

7. Kanning, U. P. \& N. Bergmann, N. (2009). Predictors of Customer Satisfaction: Testing the classical paradigms. Managing Service Quality. An International Journal, Vol.19, No. 4, pp. 377-390.

8. Oliver, R. (1980). A cognitive model of the antecedents and consequences of satisfaction decisions. Journal of Marketing Research, 17 (19), 46-49.

9. Salifu, J. D., \& Evans, M. R. (2010). The Nexus of service performance and service quality: A study of the Ghanaian retail banking industry.

10. Schiffman, G., L., Kanuk, L., L., Kumar, R., S. (2010). Consumer Behavior, (Tenth Edition), Prentice Hall: Dorling Kindersley.

11. Schnaars, S. P. (1991). A Customer Driven Approach. NY: The Free Press.

12. Tesfom, G. \& Birch, N. J. (2011). Do Switching Barriers in the Retail Banking Industry Influence Bank Customers in Different Age Groups Differently?' Journal of Services Marketing, Vol. 25, No. 5, pp.371-380

13. Wong, S. (2011). A study on the role of customer satisfaction in domestic retail banking sector. University of Malaya: Unpublished Master's thesis.

14. Zeithaml, V., \& Bitner, M. (2003). Service Marketing. Integrating Customer Focus across the Firm (3rd ed.). Boston: McGrawHill/Irwin.

15. Narteh, B. \& J. Kuada, J. (2014). Customer Satisfaction with Retail Banking Services in Ghana. Thunderbird International Business Review, Vol. 56, No. 4, pp. 353-371

16. Belás, J., Demjan, V., Holec, M., \& Chochol'áková, A. (2014). The feelings of customers while communicating with the bank in the context of buying habits. Case study from the Czech Republic and
Slovakia. Proceedings of the 19th Annual International Conference on Macroeconomic Analysis and International Finance May 29. 